\title{
Correction to: Differential gene methylation and expression of HOX transcription factor family in orbitofacial neurofibroma
}

Antje Arnold ${ }^{1}$, Eddie Luidy Imada², M. Lisa Zhang ${ }^{3}$ D, Deepak P. Edward ${ }^{2,4,5}$, Luigi Marchionni ${ }^{2}$ and Fausto J. Rodriguez ${ }^{1,2,6^{*}}$

\section{Correction to: Acta Neuropathol Commun 2020 8: 62 https://doi.org/10.1186/s40478-020-00940-7}

Following publication of the original article [1], the authors identified an error in the author name of Lisa Zhang,

- The incorrect author name is: Lisa Zhang

- The correct author name is: M. Lisa Zhang

The author group has been updated above and the original article [1] has been corrected.

\footnotetext{
Author details

'Departments of Pathology, Johns Hopkins University School of Medicine, Baltimore, MD, United States. ${ }^{2}$ Departments of Ophthalmology and Sidney Kimmel Comprehensive Cancer Center, Johns Hopkins University School of Medicine, Baltimore, Maryland (MD), USA. ${ }^{3}$ Department of Pathology, Massachusetts General Hospital, Boston, MA, USA. ${ }^{4}$ King Khaled Eye Specialist Hospital, Riyadh, Saudi Arabia. ${ }^{5}$ Department of Ophthalmology and Visual Sciences, University of Illinois College of Medicine, Chicago, IL, USA. ${ }^{6}$ Johns Hopkins University School of Medicine, Sheikh Zayed Tower, Room M2101, 1800 Orleans Street, Baltimore, MD 21231, USA.
}

Published online: 14 May 2020

\section{Reference}

1. Arnold A, Imada EL, Zhang ML et al (2020) Differential gene methylation and expression of HOX transcription factor family in orbitofacial neurofibroma. Acta Neuropathol Commun 8:62 https://doi.org/10.1186/ s40478-020-00940-7

\footnotetext{
The original article can be found online at https://doi.org/10.1186/s40478020-00940-7.

* Correspondence: frodrig4@jhmi.edu

'Departments of Pathology, Johns Hopkins University School of Medicine, Baltimore, MD, United States

${ }^{2}$ Departments of Ophthalmology and Sidney Kimmel Comprehensive Cancer

Center, Johns Hopkins University School of Medicine, Baltimore, Maryland (MD), USA

Full list of author information is available at the end of the article
}

(c) The Author(s). 2020 Open Access This article is licensed under a Creative Commons Attribution 4.0 International License, which permits use, sharing, adaptation, distribution and reproduction in any medium or format, as long as you give appropriate credit to the original author(s) and the source, provide a link to the Creative Commons licence, and indicate if changes were made. The images or other third party material in this article are included in the article's Creative Commons licence, unless indicated otherwise in a credit line to the material. If material is not included in the article's Creative Commons licence and your intended use is not permitted by statutory regulation or exceeds the permitted use, you will need to obtain permission directly from the copyright holder. To view a copy of this licence, visit http://creativecommons.org/licenses/by/4.0/. The Creative Commons Public Domain Dedication waiver (http://creativecommons.org/publicdomain/zero/1.0/) applies to the data made available in this article, unless otherwise stated in a credit line to the data. 